\title{
Teaching Moral Values Through the Film, "Children of Heaven": A Review and Qualitative Analysis of Islam as a Way of Life
}

\section{Mansoureh Ebrahimi}

Faculty of Islamic Civilization, University Technology of Malaysia (UTM), 81310 Johor Bahru, Malaysia

(Corresponding author: Mansoureh Ebrahimi) E-mail: suriebrahimi@gmail.com; mansoureh@utm.my

\section{Kamaruzaman Yusoff}

Faculty of Islamic Civilization, University Technology of Malaysia (UTM), 81310 Johor Bahru, Malaysia,

y.kamaruzaman@utm.my

Hussin Bin Salamon

Faculty of Islamic Civilization, University Technology of Malaysia (UTM), 81310 Johor Bahru, Malaysia, drhussin@utm.my

\section{Doi:10.5901/mjss.2015.v6n2s1p331}

\section{Abstract}

Islam's moral instructions for exemplary conduct as referenced in Al'Qur'ān are replete with precious family values that form an essential framework for the stabilization of all family units. This study clarifies Islam as a 'way of life' with a focus on the Iranian film "Children of Heaven" (1997, written and directed by Majid Majidi), which depicts moral values that continue to inspire children all over the globe. The film particularly highlights family values as emphasized in the Qur'ān with regard to children who perform the 'best possible' deeds for the benefit of their parents. The lessons shared by this production were examined and compared with passages in the Qur'ān using a simple qualitative survey. Our findings significantly demonstrate that "Children of Heaven" beautifully illustrates moral values that are worthy for the guidance of all children.

Keywords: The Qur'ān, "Children of Heaven", Majid Majidi, Ali, Zahra;

\section{Introduction}

Muslims hold forth that Islam was revealed to humankind through Prophet Muhammad as a guidance to achieve al-falāh (real success) ('Alī, 1410H, 23:1-11) as the revealed religion preached by all prophets of God (Al'Qur'ān 3:83; 42:13; 2:136). Hence, Islam does not deny the truth of other divinely inspired religions, particularly those sent to Prophets Mūsā (Moses) and 'Tsā (Jesus). This message was expressly revealed to guard humankind from the influence of Satan and evil desire (Al'Qur'ān, 12:53; 7:14-7) while providing correct steps towards the achievement of success in the next world.

Muslims also believe that Islam is the final revelation to humankind; one that serves as a 'way of life' both pertinent and applicable to all men and for all ages. Notably, the authenticity of the faith's origins has been preserved by the Qur'ān as well as by detailed accounts of Prophet Muhammad's life (Sunnah). These historical acts were acknowledged by R. A. Nicholson as follows:

The Koran is an exceeding human document reflecting every phase of Muhammad's relationship to the outward events of his life; so that there we have materials of unique and incontestable authority for tracing the origin and early development of Islam. Such materials do not exist in the case of Buddhism or Christianity or any other ancient religion." (Nicholson 1907).

\section{Islam: A Way of Life}

Islam requires complete submission from its followers. This deference to the divine represents the central core of the faith as a unique feature of the religion. Hence, to fulfill this condition, no discontinuity is allowed between the material and spiritual or between permanence and change (Al-Farūqī 1992; Sardar 1987); thus establishing balance between the individual and society while integrating worldly matters with life after death as embodied in the concept of al-din (a way of 
life) (Khurshid 1975). Al-dīn, which is usually wrongly translated as 'religion' (Gardet 1964), refers to a 'way of life' that includes every aspect of human activity. Muslims believe that as long as these activities are carried out in accordance with the prescribed sharī 'ah (Islamic law), and with the intention of seeking God's riộā (pleasure), the requirement of full submission is met.

It is worth noting religion, as it is understood in Western religious history, refers to an exclusive relationship between humankind and God concerning only spiritual matters (Gardet 1964). By contrast, Islam's al-din concerns the relationship between mankind and God as well as fellow humans and other creatures, including the environment, universe and self. Although the major focus is on man's relationship with God and fellow humans as a fulfillment of their duty as God's vicegerent on earth, the other relationships must not be neglected since they are part of a Muslim's responsiblity. Muslims believe that all creatures were created for humankind to carefully attend to in fulfillment of the aforementioned duty.

"Do ye not see that God has subjected to your (use) all things in the heavens and on earth, and has made His bounties flow to you in exceeding measure, (both) seen and unseen? Yet there are among man those who dispute about God, without knowledge and without guidance, and without a Book to enlighten them." (The Qur'ân 31:20).

Nevertheless, despite these many bounties, human life is full of difficulties and turmoil. The reason is that humans do not establish good relations and fail to fulfill their duties as commanded. Consequently, crises occur and abound locally, internationally, economically, politically and socially at all levels. Unfortunately, these unbecoming consequences are generally caused by vested, self-centered interests of those who are morally bankrupt and do not consider the welfare of others.

Muslims view the establishment of good relations as a part of 'ibādah (worship) in its wider sense. Consequently, they view all worldly affairs-political, social and economic-as acts of worship undertaken with good intentions in accordance with sharī 'ah. Hence, Islamic worship not only concerns an exclusive relationship between man and God, as in the West, but is applicable to all aspects of human life. One meaning of the word, 'Islam', is to surrender ourselves to God and be fully obedient to Him while making peace with others (Khurshid 1975). On this matter, Maudūdi wrote the following:

\footnotetext{
"Islam is an Arabic word and connotes submission, surrender and obedience. As a religion, Islam stands for complete submission and obedience to God. Another literal meaning of the word of Islam is 'peace' and this signifies that one can achieve real peace of body and mind only through submission and obedience to God. Such a life of obedience brings with it peace of the heart and establishes real peace in society in large." (Maudūdi 1980).
}

In other words, every human activity must be organised in accordance with the shari 'ah of Islam which is based on the paradigm of al-tawhî̀d (the oneness of God); al-'adālah (justice); and ihsān (to do good) (Al-Habshi 1989).

Al-tawhīd is an essential pre-requisite for men to establish a good relationship with God, not only to achieve success in the hereafter but also in the mundane realm. Such a worlview gives cause for concern about the self and one's relationship with our Creator while actuating the establishment of good relations with other fellows, creatures and creation.

"Thus, an invitation to al-tawhìd is an invitation to an all comprehensive and all prevading revolution, which changes not only religion but the entire system of living. It provides a new philosophy of life, new values and a new ideology which lift a man far above his fellow-beings." (Rahmmān1980.)

\section{Moral Values in 'Children of Heaven'}

Ethics or akhlāq (Arabic), are immutable teachings of great import to Islam as basic doctrines shared by all prophetic messengers. In one tradition, Prophet Muhammad (saw) said "I have not been sent except for the perfection of moral conduct," (Ahmad Ibn Hanbal 1980), indicating it was his vital mission to perfect man's moral behaviour. The primary venue for this perfection lies within the family and the scope of moral values for Islamic families is extremely broad. Indeed, family relationships extend beyond parents and children to grandparents, aunts and uncles, nephews and nieces, cousins and even neighbours. In Iran, Islamic and cultural family values are the foundation of its social structure; both are profoundly joined to principles of Islamic law and order. Indeed, the culture of family values plays a crucial role in Iranian society to maintain good relations with all others and in all aspects of life (Javidan et al. 2003). 
The 1979 Iranian Revolution's regime change brought many restrictions, especially in cinema and thus caused cinematic themes to draw closer to Islamic savor. In the last few decades a captivating flow of Iranian cinema has reflected the modern history of Iranian culture (Dabashi 2007). After the revolution, Iranian cinema declined in production, but by the 1990s several excellent productions were made by famous filmmakers. For instance, Abbas Kiarostami's "A Taste of Cherry" was awarded the Palme d'Or at the Cannes Film Festival in 1997 (Karimi 2006). Samira Makhmalbaf and Bahman Qobadi, young film-makers, won at the Cannes 2000 Festival (Dabashi, 2001). And now we have "Children of Heaven" (Bachehaye Aseman), an Iranian family drama written and directed by Majid Majidi who perfectly cast the innocent faces of his well chosen child actors. The story concentrates on a pair of shoes being shared by a brother and sister in a poor family in southern Tehran. Although financial problems bring anxious difficulties, the children do their utmost to find simple solutions. It is a delightfully touching film with heartwarming effects for all who view these two children as they face challenges and struggles that wonderfully illustrate the very core of family values.

The stars are Ali (Mir Farrokh Hashemian), a nine-year-old, and his younger sister, Zahra (Bahareh Seddiqi). The drama begins with Ali taking Zahra's old shoes to a cobbler for repair. He places them in a black plastic bag in a grocery shop where he buys potatoes for his sick mother (Fereshte Sarabandi). Unintentionally, a peddler picks them up together with stale bread and some garbage. After Ali searches for them behind a box of vegetables that crashes, he is berated by the grocer. Ali tells Zahra of her lost shoes but begs her not to tell their mother. Zahra keeps the secret. Our little heroes, who are highly regarded by their parents, decide on a scheme to share Ali's sneakers when they go to school; Zahra in the morning and Ali in early afternoon. But Ali is late for school almost daily and is ordered by the principal to leave and return only with his father.

Apart from their trouble, the children give an amazing performance of kindness and loving care with moving compassion and responsibility towards their family; helping mother with housework and a suckling baby, and shopping by Ali while understanding their parents' financial problems. Ali's father (Reza Naji) does not earn enough to manage expenses. He has not paid rent for over five months and also owes the grocer. His sole concern is to provide for the family and at the same time he instructs his children to always treat their mother well. The Qur'ān gives several verses on family values that instruct us to do good for our parents in the best way possible (Al'Qur'ān 2:83, 215; 4:36; 6:151; 17:23; 29:8; 46:15).

Everything created is for the benefit and comfort of human beings to better serve the only Creator (Al'Qur'ān 31:20; $26: 7-8 ; 45: 13 ; 79: 30-3)$. Thus, we should utilise all bounties bestowed on us in obedient submission to God, the Provider and Sustainer of the Universe. Muslims are also taught that they must strive for their livelihood in this world and that God provides everything necssary for such duty. Hence, we are meant to use our capabilities, our mind and strength to acquire and justly utilise all such providence so that benefits derive from our efforts. It is therefore obligatory for every leader of a family to find ways and means to support their families with the basic neccessities of life such as food, clothes, water and shelter. God explicitly mentions these basic needs in Al' Qur'ān (20:118-9); shelter and garments (7:26, 31, 80-1; transportion (17:70); roads, channels and communication (20:53; 21:31; 22:27; 23:22; 43:10; 71:19-20); food $(10: 24 ; 80: 24)$; water (25:50; 67:30) and others, including fire (56:71-3).

Majid Majidi's masterful film throughly represents the beauty of Islamic traditions. The characters are "upright and religious Muslims" (Gregory 2008) and Ali's father teaches the children good 'amal (action), even while cutting a sugarloaf into small pieces so as not to take even a sugar cube because it was amānah (a trusted responsibility) from the Masjid and can only be served there. The most essential condition prescribed in the shari 'ah regarding the pursuit and possession of wealth is the objective and manner of obtaining it as approved by the shari 'ah. Every noble goal is valued as a good 'amal provided the means of attaining it are also good. Consequently, the effort and work done are considered acts of 'ibādah (worship). Human beings must also possess a sense of accountability before God in their manner of dealing with wealth. All responsibilities demanded from holders of wealth and property must be fulfilled. Hence, God commands us not to spread evil in the world through wealth. Instead, humans should strive to ensure good and help others to win mardâtillāh (God's pleasure) in the hereafter (Al'Qur'ān 28:77) Also, God commands our devotion to doing good and our generosity towards others, especially relatives; but indecency, wickedness and vile conduct are forbidden (Al'Qur'ān 16:90). A case in point in "Children of Heaven" is their social network and the assistance provided to a sick neighbor when Ali's mother asks him to contribute a bowl of soup to their neighbor. Ali also gives his pen, a gift from his teacher, to his sister, Zahra. Based on Islam, humans should spend their wealth, even small contributions, in accordance with God's Will. Every single thing related to their possessions, including their methods of acquiring and spending it, will be enquired of them by God in the afterlife. One's success in the life of the hereafter, therefore, depends also on how well one manages to be a good trustee of God's bounties in this world (Al'Qur'ān 28:76-9). Hence, we should strive to spread good to other people specifically through the bounties bestowed on us by God. 
Ali's father works very hard. In the course of the story he is told that if he finds gardening work among the rich in northern Tehran he would earn good money. He then obtains the necessary tools and Ali accompanies him as they seek work in many places without success. Even so, Ali was very helpful and took great pains to explain to landowners what they could do for them. Fortunately, after a short dialogue, Ali was called by Ali Reza (Mohammad Hossein Shahidi), a boy living with his grandfather (Kazem Asqarpoor). The film depicts the loneliness of Ali Reza who asks Ali to play with him. Their lovely childishness emerges during eager fun and by the time Ali leaves, Ali Reza is fast asleep in delightful exhaustion.

The film places no blame on society as Ali struggles for a pair of shoes in the south while rich Tehranians in north require a gardener. Islam concerns itself with the well being of everyone when it comes to questions of basic needs. Hence, the welfare of a person unable to strive for his or her basic needs falls under the guardianship of the rich in a Muslim society. By default this burden initially falls on society and only to government if no one willingly accepts the responsibility. Ideally this means that no one should lack the bounties provided by God in this world as far as basic human needs are concerned. In this respect, Islam stresses that healthy, able-bodied persons must strive and work to acquire their livelihoods. The Qur'ān and Sunnah emphasise that work and labour are natural corollaries to human existence, even as the prophet strove for God's bounties as shepherd and merchant. Hence, Islam requires us to earn our livelihood and not live on charity (Al' Qur'ān 4:32). Furthermore, Islam does limit the amount of wealth a person may accumulate. An individual can acquire as much wealth as he/she can achieve as long as it is done in a correct and just manner as prescribed by sharī 'ah. Such accumulated wealth should be spent-as repeatedly stressed by the Al'Qur'ān (28:77; 61:11)_in a right and permissible way.

Islam provides much needed guidance for all aspects of life and is neither a rahbāniyyah (ascetic) nor a māddiyyah (materialistic) religion as it's teachings harmonize both (Raḥmān, 1974). The Muslim's pursuit of māddī (material) is optimally integrated with the importance of spirituality so that life in the mundane world is better guided by spiritual inclinations that ensure that every act of pursuing God's bounties is ethical. Hence, Islam integrates the material world with man's spiritual existance to assure success in both realms (Al'Qur'ān 28:77).

In view of our discussion thus far, we may conclude that Islam teaches mankind to live in the best possible manner while striving towards a comfortable life in this world as its teachings better enable our service to the Creator and Sustainer of the universe. Thus, Islam explicitly stresses that any means of acquiring wealth and using/spending it must be done in accordance with sharī 'ah. More to point, the question of 'al-halāl wa al-harām' (the lawful and the unlawful) in Islam must be soberly considered when striving to obtain the good of this world. Accordingly, Islam provides welldefined ethical guidance as a prominent feature in Islam's way of life.

\section{Conclusion}

Islam highly commends the relationship between parents and children as a moral that forms the soundest of foundations for all societies. The film "Children of Heaven" was deemed the best Foreign Language Film and was Oscar-nominated for an Academy Award in 1999. Its most esteemed achievement is the simplicity of its descriptions for numerous Islamic family values, even in the midst of poverty. Its viewing can only enhance family relationships and interactions while elevating honest and penetrating insights with contemplations of a worldview that reflects spiritual reality. The brilliant portrait of its characters teaches viewers tolerance towards adversity minus petty grumblings. "Children of Heaven" also provides a frank picture of Iranian culture that is lovingly expressed in terms of loyalty to the family, of social relationships, of high regard for elders (particularly parents), and of trustworthiness towards each other. It is especially filled with Islamic values pursuant to the 1979 Iranian Islamic Revolution, and since Malaysia holds a Muslim majority following the teachings of Al'Qur'ān, the common positive values that play a central role in both cultures as impressively displayed in "Children of Heaven" makes it a most worthy contribution of cinematic art for all Muslim families. The most noteworthy point of this review is the latter statement which implies that the film holds meaningful educational value in concert with Al'Qur'ān, and is beautifully portrayed for all those concerned with training their children in accord with Islamic family values.

\section{References}

'Alī, 'Abdullāh Yūsuf (1410H). The Holy Qur'ān: English Translation of the Meanings and Commentary. (Revised \& Edited by IFTA), Madīnah al-Munawwarah.

Aḥmad Ibn Ḥanbal (1980). Musnad Aḥmad. Dār al-Ma‘ārif, Egypt.

Al-Farūqī, I. R. (1992). AL-Tawhịd: Its Implications for Thought and Life. The International Institute of Islamic Thought, Virginia, U. S. A. 
Al-Habshi, S.O. (1989). Islam, Ekonomi dan Pengurusan (Islam, Economics and Management). Shah Alam. Hizbi Publication.

Children of Heaven (Film)

Dabashi, H. (2001). "Close Up: Iranian Cinema, Past, Present, and Future". Verso, London.

Dabashi, H. (2007). "Masters \& Masterpieces of Iranian Cinema". Mage Publishers, Washington, D. C.

Gardet, L. (1964). "al-Din" in Encyclopaedia of Islam (B. Lewis, Ch. Pellat and J. Schacht, eds.). Vol. 2. Leiden, Germany.

Gregory, A. (2008). "Majid Majidi and New Iranian Cinema". Journal of Religion and Film. vol. 12, no. 1.

Javidan, M. and A. Dastmalchian (2003). "Culture and Leadership in Iran: The Land of Individual Achievers, Strong Family Ties, and Powerful Elite." The Academy of Management Executive (1993-2005). 17(4), 127-142. doi: 10.2307/4166016.

Karimi, Z. P. (2006). "Iranian Cinema: Texts and Contexts." Art Journal, 65(2), 136-137. doi: 10.2307/20068473.

Khurshid, A. (1975). "Islam: Basic Principles and Characteristics in Islam." in Islam Its Meaning and Message (Ed. By Khurshid, A.), Islamic Council of Europe, London

Maudūdi, A.A. (1980). Towards Understanding Islam. Leicester, The Islamic Foundation. Leicester, U. K.

Nicholson, R. A. (1907). Literary History of the Arabs. Cambridge.

Raḥmān, A. (1974). Economic Doctrines of Islam. Lahore. Islamic Publication Ltd.

Raḥmān, A. (1980). Islam; Ideology and the Way of Life. The Muslims Schools Trust, London.

Sardar, Z. (1987). The Future of Muslim Civilization. Mansell Publishing Limited, London. 